\title{
Response of Established Landscape Plants to Uniconazole
}

\author{
Gary J. Keever ${ }^{1}$ and \\ Mark S. West ${ }^{2}$
}

Additional index words. growth inhibition, growth regulator, triazoles, Elaeagnus pungens, $\mathrm{x}$ Cupressocyparis leylandii.

\begin{abstract}
Summary. Uniconazole was applied once as a soil drench $(15,30$, or 45 $\mathrm{mg}$ a.i./plant) or foliar spray (500, 1000, or $1500 \mathrm{mg} \mathrm{liter}^{-1}$, about 175 $\mathrm{ml} /$ plant) to established, field-grown thorny elaeagnus (Elaeagnus pungens Thunb. Fruitlandii ) and leyland cypress [x Cupressocyparis leylandii (A.B. Jacks. \& Dallim.) Dallim. \& A.B. Jacks]. At the end of the second growing season following treatment, shoot dry weights (SDW) of thorny elaeagnus decreased with increasing rates of drench-applied uniconazole, while SDW of plants receiving the foliar application were not affected by increasing rates. Growth indices of leyland cypress, determined twice during the first growing season and at the end of the second growing season, were not influenced by application method or rate. Uniconazole applied as a soil drench at 15 to $45 \mathrm{mg}$ a.i./ plant suppressed growth of established thorny elaeagnus for at least two growing seasons, but leyland cypress was not affected by uniconazole drench or foliar spray at tested rates. No phytotoxicity was observed on either species in any treatment during the experiment.
\end{abstract}

$\mathbf{P}$ runing of landscape trees and shrubs to control excessive vegetative growth and improve plant form is a major expense in utility and landscape maintenance. The electric utility industry spends an estimated $\$ 800$ million per year for tree trimming under power lines (Watson, 1987), while hundreds of millions of

Jepartment of Horticulture and Alabama Agricultural Experiment Station, Auburn University, Auburn, AL $\$ 6849$.

Associate Professor of Horticulture.

Assistant Professor of Research Data Analysis. 
dollars are spent maintaining landscape trees and shrubs. Numerous plant growth regulators (PGRs) have been evaluated for retardation of woody plant growth, but most remain uneconomical or cause undesirable side effects (Hare, 1982; Weston et al., 1980). Several PGRs, including dikegulac sodium (Atrimmec, Hoffman-LaRoche, Nutley, N.J.), maleic hydrazide (Royal Slo-Gro, Uniroyal, Bethany, Conn.), mefluidide (Embark, PBI/Gordon, Kansas City, Mo.), and paclobutrazol (Clipper, ICI, Goldsboro, N.C.), are registered for use on ornamental trees and shrubs. All of these PGRs, except paclobutrazol, typically are applied as foliar sprays; paclobutrazol is labeled for trunk injection of trees along utility right-of-ways.

Uniconazole (Sumagic, Valent U.S.A., Walnut Creek, Calif.), a member of a group of compounds called triazoles, is a bioregulator that suppresses stem elongation by the inhibition of gibberellin acid biosynthesis. Early research indicates that this PGR can be very persistent in retarding plant growth without causing phytotoxicity (Davis et al., 1988). Uniconazole is labeled for use on bedding plants and several potted crops, but not on woody landscape plants. However, results of several tests indicate that uniconazole is effective in suppressing growth of woody landscape plants in containers (Keever et al., 1990; Norcini and Knox, 1990; Warren, 1990). The influence on field-grown landscape plants has not been studied. The container-grown woody plants evaluated in the cited references were all angiosperms. Growth retardants generally have been less effective, non-effective, or phytotoxic to gymnosperms (Hare, 1982; Weston et al., 1980). We performed this research to determine the influence of soil- and foliar-applied uniconazole on two established, field-grown woody landscape species under simulated lowmaintenance landscape conditions. Both species, Elaeagnus pungens Fruitlandii (thorny elaeagnus), an angiosperm, and $\mathbf{x}$ Cupresso cyparis leylandii (leyland cypress), a gymnosperm, exhibit very fast growth rates.

Because no data were available on approximate rates of uniconazole for gymnosperms, a preliminary experiment was conducted. Uniform liners of leyland cypress in 4-inch (10-cm) containers were repotted into \#l gal (3.8-liter) containers using a 7 pine bark : 1 sand (by volume) growth medium amended per cubic yard $\left(\mathrm{m}^{3}\right)$ with $5 \mathrm{lb}(3 \mathrm{~kg})$ dolomitic limestone, $14 \mathrm{lb}$ $(8.3 \mathrm{~kg})$ Osmocote 17N-3P-10K( 17 7-12), and $1.5 \mathrm{lb}(0.9 \mathrm{~kg})$ Micromax in Jan. 1989. Plants were grown in a heated [min. 68F (20C)] double polyethylene greenhouse. On 31 Mar. 1989, uniconazole was applied as a foliar spray or drench. A single foliar spray of $10,25,50,100,150,200$, 250,300 , or $500 \mathrm{mg} \mathrm{liter}^{-1}$ was applied using a hand-held sprayer to uniformly wet foliage and stems. A single medium drench of $1,3,5,10$, or $15 \mathrm{mg}$ a.i./pot was appliedin a volume of $1 \mathrm{oz}(30 \mathrm{ml})$. Growth indices [(height + width at the widest point + width 90 to the first width) $\div 3$ ] measured 6 weeks later were inversely proportional to uniconazole rates, regardless of application method (data not shown). Growth indices of plants sprayed with the 200 or $500 \mathrm{mg}^{-1}$ liter $^{-1}$ rate of uniconazole were $18 \%$ and $37 \%$ smaller, respectively, than those of control plants. Reduction in growth indices with drench application ranged from $7 \%$ with the $5-\mathrm{mg}$ a.i. treatment to $48 \%$ with the 15-mg a.i. treatment. Based on results of this short-term evaluation, rates higher than those that suppressed shoot growth were selected for the inground experiment because we hypothesized that older, well-established landscape plants would be less responsive to uniconazole.

The experimental site for the field test consisted of a Marvyn loamy sand soil of pH 5.5. Based on soil test recommendations, dolomitic limestone was broadcast over the planting area at $2000 \mathrm{lb} /$ acre $\left(2242 \mathrm{~kg} \mathrm{ha}^{-1}\right)$. The area was subsoiled to an 18 -inch $(46-\mathrm{cm})$ depth in the rows, and planting holes were cored to a 24 -inch $(61-\mathrm{cm})$ depth with a 24-inch (61 -cm) auger. Uniform \#1 gal (3.8-liter) plants of thorny elaeagnus and leyland cypress were planted on 4 Dec. 1988. Plants were spaced 4 feet $(1.2 \mathrm{~m})$ apart within rows, and rows were 6 feet $(1.8 \mathrm{~m})$ apart. Plants were pruned for shape on 3 May 1989, and for uniformity (24 x 24 inches $)(61 \times 61 \mathrm{~cm})$ on $12 \mathrm{Apr}$. 1990. Osmocote 17N-3P-10K (177-12) at 1 Tbsp. (12 g) per plant was topdressed around the base of each plant on 18 May 1989 and 16 Apr. 1990. Areas between plants were maintained by periodic mowing and the use of glyphosate (Roundup). No supplemental irrigation was provided.
On 12 Apr. 1990, the following uniconazole treatments were applied to both species: a single drench application of 15,30 , or $45 \mathrm{mg}$ a.i. in 500 $\mathrm{ml}$ of distilled water applied around the base of each plant; a single foliar spray of 500, 1000, or 1500 mg liter $^{-1}$ solution applied to uniformly wet foliage and stems; and a nontreated control. Spray treatments were applied using a $\mathrm{CO}_{2}$ sprayer with a \#3 conical head nozzle. Tank pressure was 20 psi and $\approx 6 \mathrm{oz}(177 \mathrm{ml})$ of solution was applied to each plant. Climatic conditions when treatments were applied were clear, $55 \mathrm{~F}(13 \mathrm{C})$, and $76 \% \mathrm{RH}$. There were seven treatments with four replicates of four plants each in a randomized complete-block design within species.

Growth indices were measured on 18 July 1990, 6 Dec. 1990, and 10 Dec. 1991 (leyland cypress only). On 18 Dec. 1991, four replicates of two plants each of thorny elaeagnus were cut at ground level, chipped using a portable shredder, and placed in a $158 \mathrm{~F}$ (70C) drying oven for 21 days before being weighed. Shoot dry weights of leyland cypress were not determined because plants appeared uniform in size and density. Rate response to uniconazole was determined by regression analysis, and planned comparisons were made with orthogonal contrasts.

Growth indices of elaeagnus were not affected by uniconazole rate when measured in July 1990, although there was a slight downward trend (from 97.7 to 87.2) with increasing drench rates (Table 1). Mean growth indices of drench-treated plants (90.9) were significantly less than those of sprayed (102.5) or untreated plants (97.7). By Dec. 1990, growth indices were similar among plants treated by the different application methods. Rate response at this time was not significant except for a quadratic response to drench rates.

Shoot growth of thorny elaeagnus plants was relatively uniform during the 2 months following pruning. Plants developed vigorous, rank shoots during the latter part of the 1990 growing season and the entire 1991 growing season, which made growth indices a poor indicator of vegetative growth after mid-Summer 1990; hence, shoot dry weights (SDW) were determined in Dec. 1991. SDW of thorny elaeagnus decreased with increasing rates of drench-applied uniconazole. SDW of 
Table 1. Response of thorny elaeagnus to drench or foliarly applied Sumagic (uniconazole).

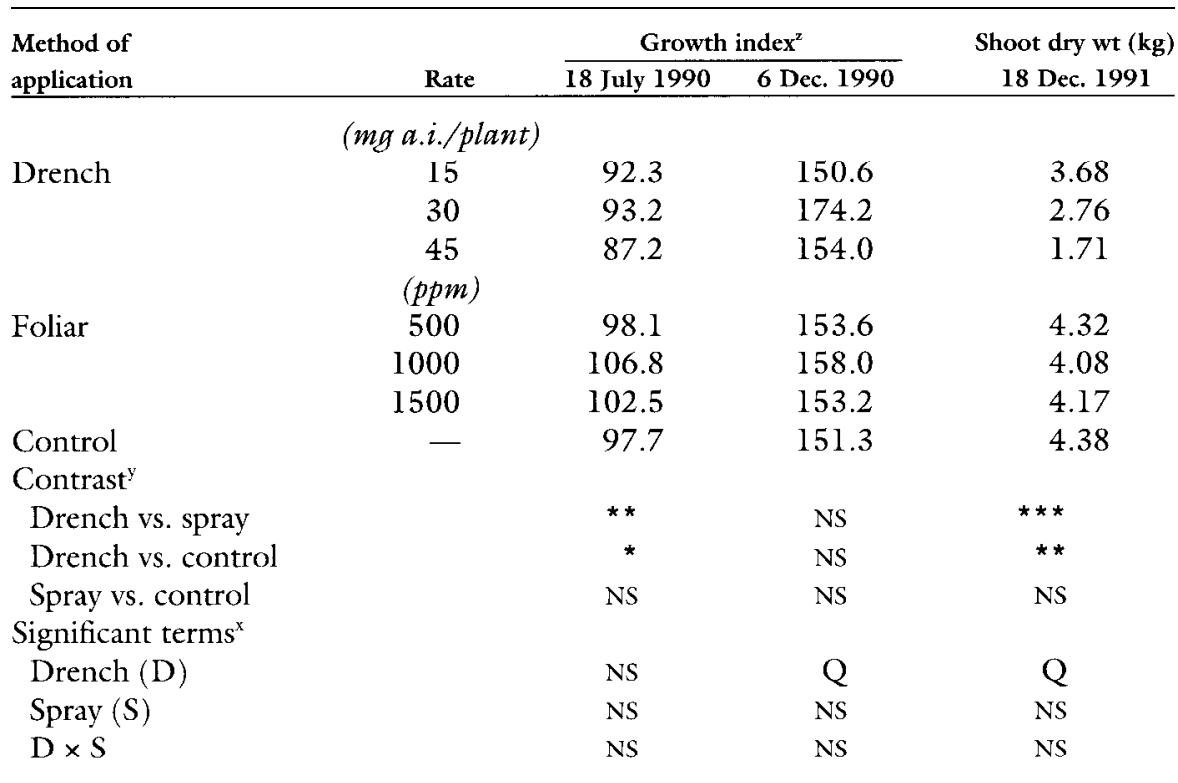

${ }^{z}$ Growth index $=\left(\right.$ height + width at widest point + width $90^{\circ}$ to first width $) \div 3$, in centimeters

${ }^{y}$ NS, ***: Nonsignificant or significant at the $5 \%$ or $1 \%$ level, respectively.

${ }^{x} N S, Q$ : Nonsignificant or quadratic response (1\% level), respectively; control included in regression analysis.

plants receiving 15,30 , or $45 \mathrm{mg}$ a.i./ plant were $16 \%, 37 \%$, and $61 \%$, respectively, less than those of control plants. Drench application resulted in significantly lower mean SDW than spray application [6.0 $\mathrm{lb}(2.72 \mathrm{~kg})$ vs. $9.2 \mathrm{lb}(4.19 \mathrm{~kg})]$ or than no treatment [9.7 $\mathrm{lb}(4.38 \mathrm{~kg})]$. SDW were not affected by increasing rates of foliarapplied uniconazole. Growth indices of leyland cypress were not influenced by application method or rate on any of the sampling dates (data not shown). All plants were densely pyramidal in form and uniform in appearance.

No phytotoxicity or foliar color differences were observed on plants of thorny elaeagnus or leyland cypress in any treatment during the experiment. Flowering of elaeagnus in Fall 1990 appeared heavier on plants receiving a drench application of uniconazole compared to those sprayed, and heavier on plants sprayed with $1500 \mathrm{mg}$ liter $^{-1}$ than on those sprayed with a lower rate or not treated. No quantitative measurements of flowering were made. These results with elaeagnus are consistent with other reports of triazoleenhanced flowering (Bailey et al., 1986; Dheim and Browning, 1988; Norcini and Knox, 1990).

Effectiveness of uniconazole in controlling vegetative growth of elaeagnus was greater with drench application than with foliar application. Differences in effectiveness of uni- conazole due to site of application concur with earlier research (Keever et al., 1990; Quinlan and Richardson, 1986; Warren, 1990), and are probably due to differences in root and foliar uptake or differences in the ability of uniconazole to be translocated in the xylem and phloem. Root-applied retardant is acropetally transported to the leaves and shoot apex primarily via the xylem (Richardson and Quinlan, 1986). Transpiration by leaves is required to pull the chemical up through the xylem to meristematic regions. There are fewer barriers against entry ofchemicals into roots than into leaves. Once inside the leaves, foliarly applied chemical would have to move through the phloem to the stem, where it might be translocated to the xylem (Barrett and Bartuska, 1982). However, in other research, no foliar-applied triazole retardant was translocated to stems or roots (Quinlan and Richardson, 1986; Wang et al., 1986), and only slight inhibition of growth resulted from leaf-lamina application (Quinlan and Richardson, 1986).

Shoot growth of leyland cypress, a gymnosperm, was not affected by uniconazole applied as either a spray or a drench, while shoot dry weight of thorny elaeagnus, an angiosperm, was reduced as much as $61 \%$ with a single drench application. Numerous growth retardants have been tested on selected conifer species. Many of these chemi- cals were phytotoxic, caused abnormal growth of seedlings and older trees, or did not reduce the plant $\mathrm{s}$ growth rate (Hare, 1982; Weston et al., 1980). Triazole retardants are potent growth regulators of a broad range of angiosperms, including monocotyledons and dicotyledons (Keever et al., 1990; Warren, 1990). Wheeler (1987) hypothesized that the anatomy of gymnosperm wood, with tracheids rather than vessels, may contribute to the lack of movement of the chemical into the crown and hence the failure of the chemical to suppress growth.

In a short-term test with recently potted liners of leyland cypress, plants were as much as $37 \%$ or $48 \%$ smaller than control plants when treated with a foliar spray or drench application, respectively, of lower concentration than that used in the field test. Differences in effectiveness may relate to plant age and/or growing environment. In other research, young gymnosperm seedlings responded to drench application of several growth retardants (Weston et al., 1980; Wheeler, 1987), while older plants ( 3 to 9 years old) were not affected by soil drench or stem injection of the growth regulator (Wheeler, 1987). Plants in our field test were well-established, having been planted 16 months prior to treatment. Soilapplied triazole retardants are relatively immobile and are most efficiently taken up by plants when both roots and inhibitor are localized in the same area (Lever, 1986). Essentially the entire root systems of container-grown leyland cypress were exposed to uniconazole, while a relatively smaller portion of the root systems of field-grown plants were treated.

In our study, drench-applied uniconazole was effective in retarding growth of in-ground thorny elaeagnus for at least two growing seasons under landscape conditions. This material could offer those involved in landscape maintenance an additional tool for managing this vigorous species. Regular, but less, pruning will still be required to remove rank shoots. Foliar spraying of uniconazole to established thorny elaeagnus was ineffective in retarding shoot growth. Uniconazole was effective in retarding growth of young, container-grown leyland cypress, but it was not effective when applied as either a foliar spray or drench to established plants under landscape conditions. 


\section{Literature Cited}

Bailey, D.A., T.C. Weiler, and T.I. Kirk. 1986. Chemical stimulation of foliar initiation in florist s hydrangea. HortScience 21:256-257.

Barrett, J.E. and C.A. Bartuska. 1982. PP333 effects on stem elongation dependent on site of application. HortScience 17:737-738.

Davis, T.D., G.L. Steffens, and N. Sankhla. 1988. Triazole plant growth regulators. Hort. Rev. 10:63-105.

Dheim, M.A. and G. Browning. 1988. The mechanism of the effect of (2RS, 3RS)paclobutrazol on flower initiation of pear cvs Doyenne du Cornice and Conference. J. Hort. Sci. 63:393-405.

Hare, R.C. 1982. Effect of nine growth retardants applied to loblolly and slash pine. Can. J. For. Res. 12:112-114.

Keever, G.J., W.J. Foster, and J.C. Stephenson. 1990. Paclobutrazol inhibits growth of woody landscape plants. J. Environ. Hort. $8: 41-47$

Lever, B.G. 1986. Cultar-A technical overview. Acta Hort. 179:459-466.

Norcini, J.G. and G. W. Knox. 1990. Effect of pruning on the growth inhibiting activity of Sumagic (uniconazole). J. Environ. Hort. 8:199-204.

Quinlan, J.D. and P.J. Richardson. 1986. Uptake and translocation ofpaclobutrazol and implications for orchard use. Acta Hort. 179:443-451.

Richardson, P.J. and J.D. Quinlan. 1986. Uptake and translocation ofpaclobutrazol by shoots of M.26 apple rootstock. Plant Growth Reg. 4:347-356.

Wang, S.Y., T. Sun, and M. Faust. 1986. Translocation of paclobutrazol, a gibberellin biosynthesis inhibitor, in apple seedlings. Plant Physiol. 82:11-14.

Warren, S. L. 1990. Growth response of 13 container-grown landscape plants to uniconazole. J. Environ. Hort. 8:151-153.

Watson, M.R. 1987. Research on tree growth regulators has exciting implications for horticulture. Amer. Nurseryman 166:70-79.

Weston, G.D., L. W. Carlson and F. C. Wambold. 1980. The effect of growth retardants and inhibitors on container-grown Pinus contorta and Picea glauca. Can. J. For. Res. 10:510-516.

Wheeler, N.C. 1987. Effect ofpaclobutrazol on Douglas fir and loblolly pine. J. Hort. Sci. 62:101-106.

\section{Acknowledgment.}

Technical assistance of Cathy Browne is gratefully acknowledged. 